\title{
What Difference Does Posthumanism Make?
}

\author{
Rachel J. Crellin ๑ \& Oliver J.T. Harris
}

In this paper we argue that to understand the difference Posthumanism makes to the relationship between archaeology, agency and ontology, several misconceptions need to be corrected. First, we emphasize that Posthumanism is multiple, with different elements, meaning any critique needs to be carefully targeted. The approach we advocate is a specifically Deleuzian and explicitly feminist approach to Posthumanism. Second, we examine the status of agency within Posthumanism and suggest that we may be better off thinking about affect. Third, we explore how the approach we advocate treats difference in new ways, not as a question of lack, or as difference 'from', but rather as a productive force in the world. Finally, we explore how Posthumanism allows us to re-position the role of the human in archaeology,

\section{Introduction}

Posthumanism is many different things. It has also been understood, and misunderstood, in multiple ways. In this paper we clarify some of the common misunderstandings about Posthumanism and offer a succinct explanation for the potential that we see in this approach. Limited by space, we do not give chapter and verse detailing the many critiques of Posthumanism, but instead focus upon clarifying four key issues. First, posthumanist approaches are multiple and there are crucial differences between them (see Cipolla, this issue; Crellin et al. 2021; Díaz-Guardamino \& Morgan 2019). Second, debates about who or what has agency continue to reproduce problematic dualisms that impede our understandings of the past; we suggest instead focusing on affect. Third, that Posthumanism facilitates a re-thinking of our concepts of difference away from the presence or absence of similarity, towards difference in itself as a productive force. Finally, in our conclusion, we set out how these three interrelated arguments re-position the role of the human. In this paper we both address common misconceptions in the field about Posthumanism and outline the productive potential of this approach.

\section{Posthumanism is multiple}

Critiques of Posthumanism often address the subject as if it were a single homogenous field. Thus we read how posthumanist or 'non-anthropocentric' approaches are not interested in discussing people, power, gender and social justice issues (e.g. Barrett 2016; Brück 2019; Ribeiro 2016; Van Dyke 2015). However, various posthumanist positions take radically different perspectives on these issues, from those which focus explicitly on worlds without humans to ones dedicated to transforming patriarchal, racist, homophobic and anti-migrant structures in the present. To describe these approaches as equally uninterested in social justice is not merely inaccurate; it actively prevents an appreciation of the potential they have to transform our understanding of the past and the present.

In this short paper it is impossible to characterize these multiple positions fully, so here we offer a sketch that highlights their variation rather than exploring the complexity of their similarities. What they do hold in common is their powerful critiques of humanism and Cartesian dualisms. It is rarely, if ever, that attacks on Posthumanism focus on this genuine shared ground; rather they take aim at

Cambridge Archaeological Journal 31:3, 469-475 @ The Author(s), 2021. Published by Cambridge University Press on behalf of the McDonald Institute for Archaeological Research. This is an Open Access article, distributed under the terms of the Creative Commons Attribution licence (http:// creativecommons.org/licenses/by/4.0/), which permits unrestricted re-use, distribution, and reproduction in any medium, provided the original work is properly cited. 
particular elements which they generalize in order to produce a blanket rejection of the field.

Perhaps the best known of the posthumanist approaches within archaeology is symmetrical archaeology. Symmetrical archaeology, like all archaeological theory, is complex and has changed over time. Harris and Cipolla (2017, ch. 10) identify two waves of symmetrical archaeology: a first wave, inspired by Bruno Latour (e.g. 2005) and his actor network theory, and a second wave more inspired by the object-oriented philosopher Graham Harman (e.g. 2011). It is this second wave upon which many critiques of Posthumanism in archaeology focus. Object-Oriented Ontology (OOO) is a form of philosophy that emphasizes how objects always exceed their relations and withdraw in part from each other and from human beings. Within OOO, humans are just one form of object alongside paintbrushes and purses. Second-wave symmetrical archaeologists have focused much of their attention on exploring the world of objects apart from the world of humans, particularly in the form of ruins (e.g. Pétursdóttir 2012; Pétursdóttir \& Olsen 2018). In such work, where humans rarely feature, it is easy to see where the critiques of an absence of concern about past and present political issues come from. Second-wave symmetrical archaeology clearly produces powerfully poetic understandings of places and things. We are not interested in critiquing these approaches or debating whether or not they are archaeology. Here we limit ourselves to identifying this important element because it contrasts clearly with other approaches.

Outside archaeology, some posthumanist approaches go further than symmetrical archaeology in their attempts to study the world besides humans. This work is often a-human, in that humans are rarely discussed (see Cipolla on ahumanism, this issue). Some of this work is a powerful critique of our anthropocentrism that has brought about the current climate crisis and has the potential to lead to human extinction on planet earth. To date such approaches have not found a home within archaeology.

An alternative posthumanist position comes from the work of Karen Barad (2007), which has been employed in archaeology by Chris Fowler (2013) and Yvonne Marshall and Ben Alberti (2014), among others. Barad draws upon quantum physics to argue that phenomena are fundamentally unstable and emergent. Her work is posthumanist because it fundamentally questions the boundaries of human beings and things and takes a radically relational approach to the notion of truth. Marshall and
Alberti (2014) combine Barad's concept of agential realism, and her feminism, with Eduardo Viveiros de Castro's (2010; 2013) ideas of Amerindian perspectivism, which foregrounds the potential for radical ontological difference to emerge. Their work explicitly seeks to recognize the reality of Indigenous knowledge and to elevate it to the status of theory. They adopt a position where multiple different worlds exist and encounter each other both ethnographically and archaeologically. Such a position clearly advocates for a powerful political position for indigenous groups. As we have explored elsewhere (Harris \& Crellin 2018), it is an open question how applicable this approach is to all areas of archaeology.

In contrast to the above versions of Posthumanism, the position we take is explicitly feminist, Deleuzian and new materialist. The first element of this, drawing extensively on the work of Rosi Braidotti (2013; 2019), foregrounds the argument that humanism always privileges specific forms of humanity, and arranges human beings into a hierarchy with the white, able-bodied, Euro-American, heterosexual man firmly at the top. A posthumanist position, from this perspective, is precisely about not imposing ideas of hierarchy, or drawing a firm boundary around who or what gets to count as human. The Deleuzian elements of this emphasize the critical importance of affect and difference (which we detail below) alongside a stringent attention to how the world is emergent, not fixed, and in the process of change all of the time, even if that change takes place at temporalities outside human awareness (Crellin 2020). This approach rejects binary oppositions between nature and culture, and is fundamentally relational: it argues that the elements of the world we recognize around us (e.g. people, things, monuments) emerge through relations. From this commitment to relations comes a new materialist position which recognizes that the world itself, not only the human beings within it, is relational. New Materialism emphasizes the contribution that matter makes to its own becoming, how the properties and capacities of materials like clay are critical to the making of objects like pots, and how the capacities of non-humans like rivers come to shape landscapes and their interactions with humans and animals (Cipolla \& Allard 2019).

There are clear elements which cross over between the approach we advocate and first-wave symmetrical archaeology (it is relational and antidualist) and the Deleuzian-inspired elements of Viveiros de Castro's thought. However, our approach 
differs from symmetrical archaeology in emphasizing the ongoing becoming of the world, the manner in which it maps processes of change, and in its attempts to explore and explain specific past contexts (Crellin 2020). It differs from the work of archaeologists inspired by Viveiros de Castro in explicitly seeking a meta-ontology (cf. Alberti 2016), albeit a metaontology that emphasizes the constant emergence of difference, as we will see below (Crellin et al. 2021; Harris in press). Fundamentally, the posthumanist position for which we advocate is committed to social justice in the present, to political transformation and to specific historically located understandings of the past. It is a form of embedded and situated critique of Western-Cartesian thinking (Sundberg 2014). Rather than denying the importance of humans, it radically transforms the assumptions we hold about our own species and provides a more accurate understanding of the historical becoming of ourselves and our worlds.

Having set out that Posthumanism covers a range of different approaches, and therefore that critiques need both to understand this variety and to identify which elements they are critiquing, we now move forward to clarify some critical issues that emerge from the particular feminist-Deleuzian-new materialist position we advocate. We begin by rethinking affect and agency.

\section{Agency and affect from a posthuman perspective}

One of the many misunderstandings that has arisen around Posthumanism is the role of agency, and particularly the vexed questions of so-called object agency. Many authors associate arguments about Posthumanism and New Materialism with the claim that these positions support the idea of object agency: that objects can have an effect on the world in a manner at least analogous, and sometimes identical, to human beings. This position is often associated inaccurately with the work of Latour. Latour $(2005,76)$, one notable and misleading chapter title aside, is not an advocate of object agency-how could he be, when he attempts to dissolve distinctions like subject and object? For Latour, agency is a product of relationships between what he terms actants-which can be anything from a microbe to a microchip. Agency here is historically situated because it depends on specific relations; it emerges neither from human beings, nor from any material things they interact with. The agency the archaeologist and the trowel have is different to the agency either has by itself (Edgeworth 2012; Witmore 2007, 552).
Latour's emphasis on a relational version of agency has much to recommend it. Nonetheless, it remains modelled on a concept that continues to have associations with particular forms of gendered actors and with particular visions of humanity. Indeed, the continued use of the term agency is a critical reason for the continuing misunderstanding of Posthumanism. If your understanding of agency is closely linked to intentionality, that it is something that rational human actors exercise, and thus something for which people, past and present, can be held accountable, it is little surprise that you might be alarmed by hearing that chairs, keys, or guns can also be associated with agency. Therefore the debate about agency in archaeology has largely outlived its usefulness; we are indeed 'beyond agency' (Robb 2010).

In its place we advocate a turn to affect. Affect has had some impact in archaeology (e.g. Hamilakis 2013; 2017; Harris \& Sørensen 2010; Jones \& Cochrane 2018), although it has largely focused on its connections with specific things like emotion, the senses and art. We argue for a more fundamental re-orientation around affect as one of the critical building blocks of the relations that constitute past and present worlds (Crellin et al. 2021, ch. 2). Drawing on the specific trajectory of thought that runs from Baruch Spinoza via Henri Bergson, Gilles Deleuze, Brian Massumi and more, we can see affect as a critical element for describing the capacities of the bodies, human and non-human, that make up worlds past and present. For Spinoza, whose philosophy forms perhaps the critical element for this line of thought, affect represents the capacity for bodies to affect and be affected, that is, their sensitivity to relations, and the way in which they form relations with other bodies around them. In a famous example, Deleuze (1988, 124) draws upon Jakob von Uexküll to consider how a tick has three affects connected to a sensitivity to light, a sensitivity to smell and a sensitivity to warmth. These three affects allow the tick to engage with the world, to climb to the top of branches led by light, to plummet onto the back of a mammal led by smell and to find the right place to burrow into the skin led by the warmth of the blood.

Affects, then, are the capacities a body has to be affected by the world and to affect the world around it. These capacities are clearly historically situated and emergent, and do not have to be exercised at any one moment to be real. The capacities human beings have today to read, for example, are not historically eternal, but emergent, and you do not have to be reading at the moment to be able to read later today or tomorrow (cf. Harman 2009, 
127-30). The capacity that a computer has to connect you to the internet depends upon a multitude of relations, any one of which may vanish, changing what it is that a specific non-human body can do. Rather than talking about generalized 'agency', we are immediately led into the discussion of specific forms of emergent, relational and contingent capacity. We can also add to this by thinking not just of the capacity to affect and be affected, but the changes that come with being affected in this way. If you are a coeliac, you not only have the capacity to be affected by gluten in specific ways; the act of actualizing this capacity has a range of deeply unpleasant feelings that accompany it, changing in turn your ability to act in other ways. Spinoza ([1667]1996) distinguishes between affect, the capacity, and affections, the experience of the change that accompanies a capacity being activated. Deleuze and Guattari $(2004,283)$ talk about a body being made up of capacious affects: on the one hand, the power potentially to act, and on the other the current state of a body at one moment in the act of being affected. They refer to these as forms of co-ordinates, latitude in the former case and longitude in the latter, and it is by mapping these co-ordinates that we can answer the question Spinoza poses for us: what is it that a body can do (Deleuze 1988)?

One brief archaeological example illustrates our point. During the Bronze Age, new forms of weaponry such as swords emerged. These have been taken to be symbols of a warrior elite (Kristiansen 1998). What happens when we take a view rooted in affect? Rather than thinking about how swords are produced to meet the needs of warriors, or how warriors are made by access to swords, we can consider how both sword and warrior emerge in parallel, through the way they produce a particular body capable of certain affects. These include the capacity to inflict violence, not in a generic way, but rather in a particular manner, involving specific bodily movements (slashing, stabbing). The emergence of swords does not allow the emergence of warriors, nor does the emergence of warriors allow the emergence of swords; rather the two are brought into being together. Swords and warriors are not static bounded categories; rather what a sword is and who a warrior is change through time. As the relations they are part of shift, different capacities and affects emerge. The Bronze Age sword made at 1200 cal. BC had the ability to slash and stab; at $1900 \mathrm{AD}$ it had the capacity to be typologized and display the progress of 'man' in a museum; today the surface has the capacity to allow wear-analysis.

\section{Difference in itself}

The next intervention we make is to emphasize the need radically to rethink difference. In traditional models, difference is understood as the presence or absence of similarity. Thus, two pots can be compared in terms of whether one is taller than the other, the presence or absence of handles, how narrow the mouth is, whether the rim is inverted or not, and so on. Differences in decoration similarly may be about the presence or absence of cordons or impressions, or the different heights of carinations. From a Deleuzian perspective, and similarly for feminist posthumanists like Braidotti, difference does not operate in this manner. Instead, difference is a productive force of differentiation that brings the world into existence (Deleuze 2004; cf. Bickle 2020). We can consider how a potter's hands apply force to clay to differentiate a shape from the previous amorphous matter. This, of course, draws on the capacities of clay to be shaped, and works with the water softening the material and the wheel upon which the clay is spinning-this is no simple imposition of form. These intensive differences of force are what drive the emergence of the entities we recognize in the world around us, from how intensive differences in pressure produce weather patterns, or the intensive energies of sunlight cause plants to grow in specific ways. Difference, then, is not after the fact, a matter of post hoc comparison, but rather an affirmative force that produces the world.

Archaeology has always depended on the traditional model of difference; it allows us to classify one pot as a Bronze Age Collared Urn and another as a Neolithic Grooved Ware pot. The presence or absence of a collar or incised grooves allow the specialist to identify these as different types from different periods. The issue with this is three-fold. First, it implies an ideal form against which the particular pot is measured. Second, it implies that these ideal forms are static, bounded and exist outside of history. Third, these bounded forms mean that the complex relations between vessels are downplayed: a pot has to either be one kind or another; traditional narratives suggest it should be identifiable because it was produced by a potter who knew in advance what kind of pot they were making. The idealist assumptions that underlie typology rest upon the same notions of difference that underpinned culture historical approaches to the past, and it is little surprise that the two are so tightly interwoven.

This relationship to culture history is critical because it is not just pots that have been classified in this way, but people too. In archaeology this has 
been a classification in terms of cultural groups ('the Beaker Folk', etc.) currently seeing a resurgence thanks to aDNA (Crellin \& Harris 2020), but more widely this version of difference underpins the typologizing and ranking of human beings. Seeing difference as negative, and measuring the distance from an ideal type, inevitably leads to comparison where some people are valued differently to others. The vision of the 'ideal human' that matches our typologist's ideal pot is almost always implicitly male, adult, white, heterosexual, able-bodied and educated (Braidotti 2013). This view of difference produces those who do not meet the standard as less than this: women are 'less stable', 'more emotional', and other sexist tropes. Similarly, racial difference is understood in even more problematic ways. The intersection of differences here, understood negatively, becomes especially pernicious. This way of thinking about difference casts the majority of us as always less than the ideal.

Switching to a Deleuzian version of difference in itself is not, in any way, about supressing or denying variation. By celebrating difference as the productive becoming of the world, we can conceptualize how the patterns we encounter emerge through shared processes, not through shared form. This approach does not suggest that men and women, or Grooved Ware and Collared Urns, are the same as each other, but it argues that their differences are produced, immanently, through historical process, and not through comparison with a transcendent ideal. This contrast between immanence and transcendence rests at the heart of the philosophies of Spinoza and Deleuze. They seek to explore the world through its constant emergence, not by reference to elements existing outside history. Thus this approach recognizes the very real processes that produce men and women as different, not as eternal oppositions, but located historical events. Women are prevented from having equal pay with men because of historical, social and political structures, not because of some fundamental, eternal difference.

The emphasis upon difference, here, also stresses where critics of the 'flat ontology', upon which much of Posthumanism is based, have fundamentally missed the point. A flat ontology suggests that we cannot know in advance what the differences are between various components of the world. In a Western ontology we readily elevate people above animals, and animals above things; however, in a flat ontology we begin from a position that does not presume in advance that people sit at the 'ontological apex' (Bennett 2010, ix). This is not to say that people cannot or did not ever understand themselves in this way, but that we need to demonstrate that historically, rather than presuming it was the case. More than this, mapping difference in itself, the Deleuzian version of difference we have outlined here, means that we cannot take the world for granted. Far from homogenizing everything, that is, saying people and things are the same, or that there are no differences between organic and inorganic matter, this perspective looks at the specific and productive force of difference at first hand. The flat ontology proposed is fundamentally dynamic, in the terms outlined by Craig Cipolla (this issue).

\section{Conclusion: the place of the human}

To conclude, we address perhaps the most common critique of Posthumanism: that as archaeologists we could never be non-anthropocentric; that the central position of human beings to our discipline means they must always take centre stage. In this paper we have argued Posthumanism is multiple, and while there are some branches that seek to move away from the study of humans, most do not. The kind of Posthumanism that we espouse is one that argues that human beings are one of many components that make up our world, and that they cannot be understood apart from the wider relational assemblages, and the specific historical processes, of which they are part. The point here is not that Posthumanism suggests we should not study human beings, rather that we cannot unless we position them within this relational matrix. If an alien were to come to earth, we would not tell them that women were less than men, yet that alien might comment upon the fact that women get paid less, educated less, and are the victims of more violent sexual attacks. We would explain to the alien that it is not the case that this is eternally true, or true of humans in a vacuum; rather it is a product of relationships with things, animals, plants, power structures and politics that have emerged over 3000 years. If you want to understand why humans are the way they are, in all their complex historical vibrancy, you cannot possibly begin with a position that places those humans outside history, ready to be slotted into your predefined period. You have to begin with a flat ontology, that opens you up to the differences that make those worlds, to the ways in which different bodies, human and non-human, have the capacity to affect each other and to be affected in turn, and how all these things are historically immanent, not transcendent. This means we seek an archaeology that is not non-anthropocentric, but rather post-anthropocentric, a move which 
marks this as different to the OOO-inflected intentions of symmetrical archaeology and binds us to the posthumanist feminist accounts we find so inspirational (Braidotti 2013; 2019; Ferrando 2019; cf. Crellin 2020; Crellin et al. 2021). A switch to Posthumanism is both a pledge to recognizing the radically different possibilities for human existence and an ethical commitment to experimenting with those possibilities to develop a world in which no single person is less than another. Archaeology's role in this is to open up our pasts to these differences, and through that to broaden our understandings of the present. To do so requires an accurate definition of what is meant by Posthumanism by both its supporters and its critics.

\section{Acknowledgements}

Many thanks to Manuel Fernández-Götz, Guillermo Díaz de Liaño and Andrew Gardner for their invitation to contribute to this special edition. In addition, we are very grateful to our colleagues who have helped us think about these issues, most notably Emily Banfield, Craig Cipolla, Hannah Cobb and Yvonne O'Dell: their help has certainly made a difference! Writing this article was partly supported by a Philip Leverhulme Prize (PLP-2016-109). The usual disclaimers apply.

Rachel J. Crellin Archaeology and Ancient History University of Leicester University Road Leicester LE1 7RH $U K$ Email:rjc65@le.ac.uk

Oliver J.T. Harris Archaeology and Ancient History University of Leicester University Road Leicester LE1 7RH $U K$ Email:ojth1@leicester.ac.uk

\section{References}

Alberti, B., 2016. Archaeologies of ontology. Annual Review of Anthropology 45, 163-79.

Barad, K., 2007. Meeting the Universe Halfway: Quantum physics and the entanglement of matter and meaning. Durham (NC): Duke University Press.

Barrett, J.C., 2016. The new antiquarianism? Antiquity 90, 1681-6.

Bennett, J., 2010. Vibrant Matter: A political ecology of things. London: Duke University Press.
Bickle, P., 2020. Thinking gender differently: new approaches to identity difference in the central European Neolithic. Cambridge Archaeological Journal 30, 201-18.

Braidotti, R., 2013. The Posthuman. London: Polity.

Braidotti, R., 2019. A theoretical framework for the critical posthumanities. Theory, Culture and Society 36(6), 31-61.

Brück, J., 2019. Personifying Prehistory: Relational ontologies in Bronze Age Britain and Ireland. Oxford: Oxford University Press.

Cipolla, C.N. \& A. Allard, 2019. Recognising river power: watery views of Ontario's fur trade. Journal of Archaeological Method and Theory 26, 1084-105.

Crellin, R.J., 2020. Change and Archaeology. London: Routledge.

Crellin, R.J., C.N. Cipolla, L.M.M. Montgomery, O.J. T. Harris \& S.V. Moore, 2021. Archaeological Theory in Dialogue: Situating relationality, ontology, posthumanism and Indigenous paradigms. London: Routledge.

Crellin, R.J. \& O.J.T. Harris, 2020. Beyond binaries: interrogating ancient DNA. Archaeological Dialogues 27, 37-56.

Deleuze, G., 1988. Spinoza: Practical philosophy. San Francisco (CA): City Lights Books.

Deleuze, G., 2004. Difference and Repetition. London: Bloomsbury.

Deleuze, G. \& F. Guattari, 2004. A Thousand Plateaus: Capitalism and schizophrenia. London: Continuum.

Díaz-Guardamino, M. \& C. Morgan, 2019. Human, transhuman, posthuman digital archaeologies: an introduction. European Journal of Archaeology 22(3), 320-23.

Edgeworth, M., 2012. Follow the cut, follow the rhythm, follow the material. Norwegian Archaeological Review 45, 76-92.

Ferrando, F., 2019. Philosophical Posthumanism. London: Bloomsbury.

Fowler, C., 2013. The Emergent Past: A relational realist archaeology of Early Bronze Age mortuary practices. Oxford: Oxford University Press.

Hamilakis, Y., 2013. Archaeology and the Senses: Human experience, memory and affect. Cambridge: Cambridge University Press.

Hamilakis, Y., 2017. Sensorial assemblages: affect, memory and temporality in assemblage thinking. Cambridge Archaeological Journal 27(1), 169-82.

Harman, G., 2009. Prince of Networks: Bruno Latour and metaphysics. Melbourne: Re.Press.

Harman, G., 2011. The Quadruple Object. Winchester: Zero Books.

Harris, O.J.T., in press. Assembling Past Worlds: Materials, bodies and architecture in Neolithic Britain. London: Routledge.

Harris, O.J.T. \& C.N. Cipolla, 2017. Archaeological Theory in the New Millennium: Introducing current perspectives. London: Routledge.

Harris, O.J.T. \& R.J. Crellin, 2018. Assembling new ontologies from old materials: towards multiplicity, in Rethinking Relations and Animism: Personhood and materiality, eds. M. Astor-Aguilera \& G. Harvey. London: Routledge, 55-74. 
Harris, O.J.T. \& T.F. Sørensen, 2010. Rethinking emotion and material culture. Archaeological Dialogues 17(2), 145-63.

Jones, A.M. \& A. Cochrane, 2018. The Archaoelogy of Art: Materials, practices, affects. London: Routledge.

Kristiansen, K., 1998. Europe Before History. Cambridge: Cambridge University Press.

Latour, B., 2005. Reassembling the Social: An introduction to actor-network-theory. Oxford: Oxford University Press.

Marshall, Y. \& B. Alberti, 2014. A matter of difference: Karen Barad, ontology and archaeological bodies. Cambridge Archaeological Journal 24(1), 19-36.

Pétursdóttir, P., 2012. Concrete matters: ruins of modernity and the things called heritage. Journal of Social Archaeology 13(1), 31-53.

Pétursdóttir, P. \& B. Olsen, 2018. Theory adrift: the matter of archaeological theorizing. Journal of Social Archaeology 18(1), 97-117.

Ribeiro, A., 2016. Against object agency. A counterreaction to Sørensen's 'Hammers and nails'. Archaeological Dialogues 23(2), 229-35.

Robb, J., 2010. Beyond agency. World Archaeology 42(4), 493-520.

Spinoza, B., [1667]1996. Ethics. London: Penguin.

Sundberg, J., 2014. Decolonizing posthumanist geographies. Cultural Geographies 21(1), 33-47.

Van Dyke, R., 2015. Materiality in practice: an introduction, in Practicing Materiality, ed. R. Van Dyke. Tucson (AZ): University of Arizona Press.
Viveiros de Castro, E., 2010. Intensive filiation and demonic alliance, in Deleuzian Intersections: Science, technology, anthropology, eds. C.B. Jensen \& K. Rödje. Oxford: Berghahn, 219-54.

Viveiros de Castro, E., 2013. The relative native. HAU: Journal of Ethnographic Theory 3(3), 473-502.

Witmore, C.L., 2007. Symmetrical archaeology: excerpts of a manifesto. World Archaeology 39(4), 546-62.

\section{Author biographies}

Rachel J. Crellin is Lecturer in Archaeology at the University of Leicester. Her research interests centre on archaeological theory, especially new materialist, feminist and posthumanist approaches. She is also a specialist in the Neolithic and Bronze Age of Britain, Ireland and the Isle of Man, and a metalwork wear-analyst. She is the author of Change and Archaeology (Routledge, 2020).

Oliver J.T. Harris is Associate Professor of Archaeology at the University of Leicester. He is co-author of The Body in History (Cambridge University Press, 2013), Archaeological Theory in the New Millennium (Routledge, 2017) and Archaeological Theory in Dialogue (Routledge, 2020). He researches new materialist, posthumanist and Deleuzian approaches to the past. He has just finished a book entitled Assembling Past Worlds for Routledge. 